\title{
Tree species composition in areas of Atlantic Forest in southeastern Brazil is consistent with a new system for classifying the vegetation of South America
}

Pedro Vasconcellos Eisenlohr ${ }^{1,2}$ and Ary Teixeira de Oliveira-Filho ${ }^{1}$

Received: 10 June, 2013. Accepted: 5 November, 2013

\begin{abstract}
Rigorous and well-defined criteria for the classification of vegetation constitute a prerequisite for effective biodiversity conservation strategies. In 2009, a new classification system was proposed for vegetation types in extra-Andean tropi$\mathrm{cal}$ and subtropical South America. The new system expanded upon the criteria established in the existing Brazilian Institute of Geography and Statistics classification system. Here, we attempted to determine whether the tree species composition of the formations within the Atlantic Forest Biome of Brazil is consistent with this new classification system. We compiled floristic surveys of 394 sites in southeastern Brazil (between $15^{\circ}$ and $25^{\circ} \mathrm{S}$; and between the Atlantic coast and $55^{\circ} \mathrm{W}$ ). To assess the floristic consistency of the vegetation types, we performed non-metric multidimensional scaling (NMDS) ordination analysis, followed by multifactorial ANOVA. The vegetation types, especially in terms of their thermal regimes, elevational belts and top-tier vegetation categories, were consistently discriminated in the first NMDS axis, and all assessed attributes showed at least one significant difference in the second axis. As was expected on the basis of the theoretical background, we found that tree species composition, in the areas of Atlantic Forest studied, was highly consistent with the new system of classification. Our findings not only help solidify the position of this new classification system but also contribute to expanding the knowledge of the patterns and underlying driving forces of the distribution of vegetation in the region.
\end{abstract}

Key words: classification consistency, NMDS ordination, tree flora, vegetation types

\section{Introduction}

Brazil harbors nearly $20 \%$ of the global flora, making it the most biodiverse region in the world (Giulietti et al. 2005). The Atlantic Forest Biome, in particular, is one of 35 areas listed as global hotspots for wildlife conservation (Myers et al. 2000; Mittermeier et al. 2004; Zachos \& Habel 2011). The richness of angiosperms in this biome has recently been estimated at over 13,000 species, half of which are endemic (Stehmann et al. 2011). Approximately 85\% of the endemic species are concentrated in the so-called "biodiversity corridors" (Werneck et al. 2011). There are places with extraordinary tree species diversity, such as the town of Santa Teresa, in the state of Espírito Santo, where Saiter et al. (2011) recorded a Shannon index $\left(H^{\prime}\right)>5$, and the Serra do Mar State Park, in the state of São Paulo, where Joly et al. (2012) detected more than 200 species in each of two 1-ha plots. Despite the high levels of diversity and endemism, the degree of threat to the conservation of the Atlantic Forest is alarming (Myers et al. 2000; Mittermeier et al. 2004; Ribeiro et al. 2011), the forest cover having been reduced to $11.4-16 \%$ of its original extent (Ribeiro et al. 2009).

These impressive figures show that conservation strategies require rigorous and well-defined criteria for vegetation classification, because the correct and incorrect use of language still has serious implications for conservation issues (Oliveira-Filho \& Fontes 2000; Coutinho 2006; Batalha 2011). Since the first attempt, by Martius in 1824, to classify the vegetation of Brazil, several systems have been proposed (Veloso et al. 1991; Fernandes 2000). The system that is now the most widely used is the Instituto Brasileiro de Geografia e Estatística (IBGE, Brazilian Institute of Geography and Statistics) system of classification (Veloso et al. 1991, IBGE 2012), which resulted from decades of research under the Radar in Amazonia Project. In the classification systems of the vegetation of Brazil, one can find various attempts to assign standardized nomenclature to the main vegetation types (Veloso et al. 1991; IBGE 2012). Elevational variations, for example, are often contemplated in these systems, with assigned ranges, such as lowland, submontane and montane (Veloso et al. 1991; IBGE 2012). On the basis of the IBGE

1 Universidade Federal de Minas Gerais, Instituto de Ciências Biológicas, Departamento de Botânica, Belo Horizonte, MG, Brazil

2 Author for correspondence: pedrov.eisenlohr@gmail.com 
system, Oliveira-Filho (2009) proposed a new classification system for vegetation types in extra-Andean tropical and subtropical South America, aimed primarily at describing vegetation types at finer scales than those allowed by the IBGE system ( $<1: 10$ vs. $<1: 100,000)$. Because of its finer scales, the new system also allows the incorporation of ecological features that cannot be evaluated with the IBGE scale, particularly those related to soils, topography and drainage. As a starting point, the new system defines five main vegetation formations-forest, scrubland, savanna, grassland and man-made - which are subdivided into 16 first order vegetation types. That is the first level of classification, which deals with topological aspects of the plant mass, such as height, openness and leaf texture (e.g., broadleaved dwarf forest, stiff-leaf scrub, and parkland savanna). From there, up to five hierarchical attributes may be appended to make up the vegetation types, though the author stresses that some levels should be omitted as necessary, because the system is intended to allow flexibility in the interest of user-friendliness. The five levels include climatic regime (rain, cloud, seasonal, semi-arid and maritime), leaf-flush regime (evergreen, semideciduous, deciduous, alternate and ephemeral), thermal regime (tropical/subtropical), elevational belt (coastal, lower plains, upper plains, lower highlands, and upper highlands) and substrate (sandy, rocky, eutrophic, slope, etc.). While the IBGE lists 28 formations, the new system-hereafter referred to as the Oliveira-Filho system (Oliveira-Filho 2009) - allows up to 202 combinations, if the substrate is disregarded. Nevertheless, because of the above-mentioned flexibility, the user rarely needs to apply all levels.

To date, there have been no studies verifying the validity of this new system for use with the vegetation of Brazil. Here, we intend to initiate this effort, focusing on the Atlantic Forest Biome in southeastern Brazil. We chose this region because there have been a great number of floristic surveys conducted in the region, thereby allowing a robust analysis of the vegetation patterns. We attempted to determine whether the tree species compositions of formations within the Atlantic Forest Biome are consistent with the OliveiraFilho system, or rather, whether the floristic groups meet the criteria of the new system. We expected that to be the case, because a few studies conducted in this biome (e.g., Oliveira-Filho \& Fontes 2000; Oliveira-Filho et al. 2005; Marques et al. 2011; Santos et al. 2011) have found a close relationship between tree vegetation patterns and certain Oliveira-Filho system criteria, mainly those related to physiognomy, climatic regime, and elevational belt.

\section{Material and methods}

\section{Preparing the database}

We compiled floristic surveys of 394 sites in southeastern Brazil (between $15^{\circ}$ and $25^{\circ} \mathrm{S}$; and between the Atlantic coast and $55^{\circ} \mathrm{W}$ ), encompassing the states of Espírito Santo, Rio de Janeiro, Minas Gerais, and São Paulo, as well as parts of the states of Bahia, Paraná, and Mato Grosso do Sul (Fig. 1), which is the same geographic frame used in an earlier study by Oliveira-Filho \& Fontes (2000). We classified all sites down to the fifth level of the Oliveira-Filho system, and we added two elevational ranges (lower montane and upper montane), in accordance with ongoing (as yet unpublished) improvements being made to the system. Thus, we created a species matrix containing binary occurrence records of 3332 species.

\section{Data analysis}

To assess the floristic consistency of the vegetation types, we performed two analyses of the species matrix: an ordination (exploratory) analysis and a (confirmatory) ANOVA. To ordinate the sites, we used non-metric multidimensional scaling (NMDS), as previously described (McCune \& Grace 2002; Wildi 2010), with the PC-ORD program, version 6.0 (McCune \& Mefford 2011), choosing the Bray-Curtis distance measure. We confirmed the stability of the "stress" at the end of the iterations, as recommended by McCune \& Grace (2002). The "stress" is a measure of departure from monotonicity in the relationship between distances in the original space and in the reduced ordination space (McCune \& Grace 2002). We performed 999 permutations to generate the statistical significance of the axes. For each axis, we obtained the coefficient of determination $\left(R^{2}\right)$ for the correlations between ordination distances and the distances within the original $n$-dimensional space.

To confirm the floristic variation obtained from the NMDS, we applied multifactorial ANOVA (Zar 2010) to the site scores of each axis. The factors were the classification criteria of the vegetation types. For factors with significant effects, we performed Tukey's post hoc honestly significant difference tests, adjusted for an unequal number of sample units (Smith 1971). We confirmed the assumptions of normality of the residuals and homogeneity of variances by Lilliefors test coupled with a hump-shaped histogram and by Hartley tests, respectively (Zar 2010). When necessary to meet these assumptions, we eliminated outlier sites, assumed as those with disparate standardized residuals.

We checked whether the ANOVA residuals showed spatial structure, because, if so, corrective measures would be adopted (Diniz-Filho et al. 2003; Diniz-Filho \& Bini 2005). We assessed the spatial structure of the residuals by Moran's I correlograms and based our decision-making on the global significance of the correlograms using sequential Bonferroni correction (Fortin \& Dale 2005). We used this correction to avoid a bias in the significance test, given that several tests were performed with the same dataset. When ANOVA residuals showed significant spatial structure, we added spatial filters (Diniz-Filho \& Bini 2005) by the principal coordinates of neighbor matrices method (Borcard \& 


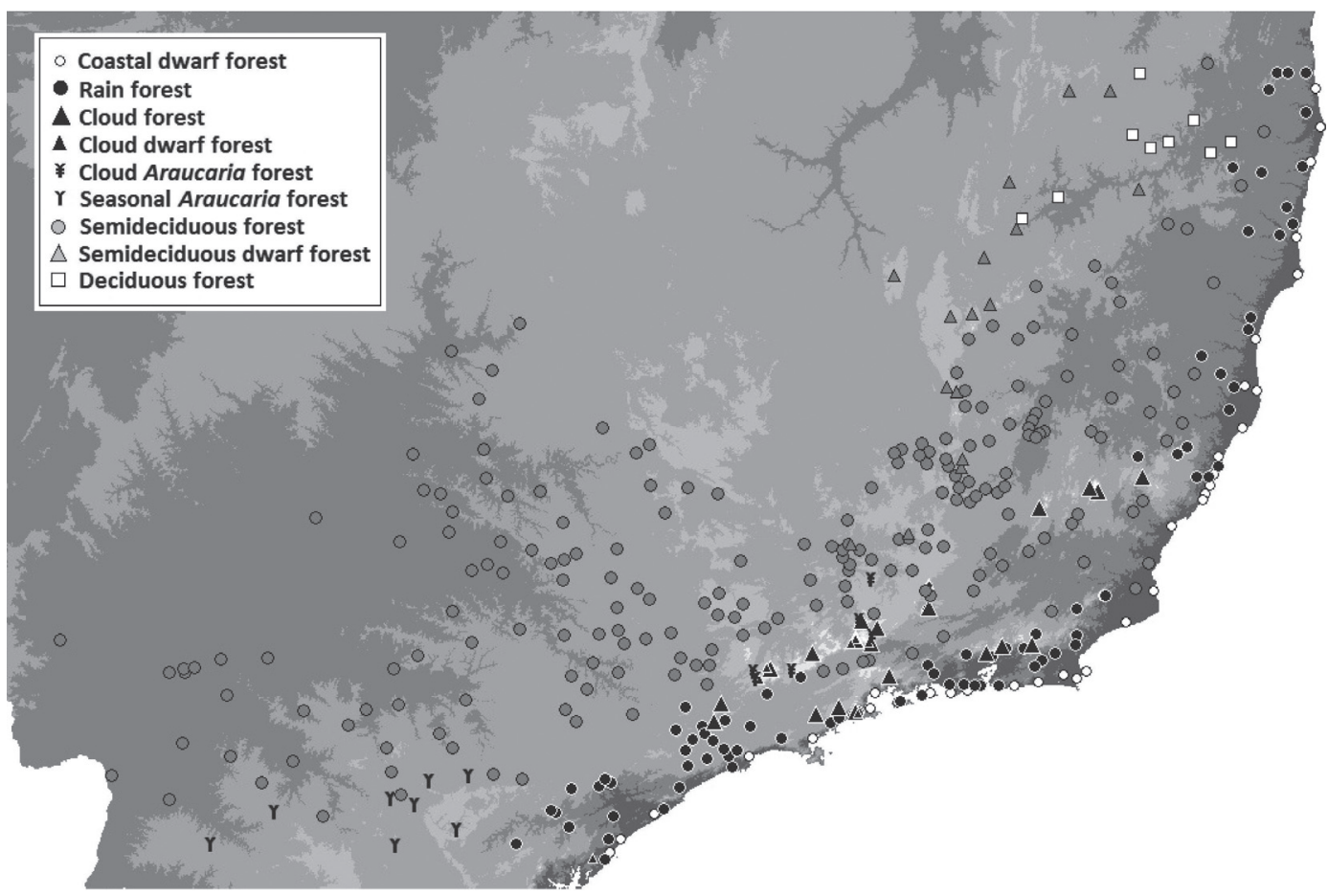

Figure 1. Locations of the 394 surveys compiled for analysis and their general vegetation types.

Legendre 2002). The use of spatial filters is an interesting strategy for modeling the spatial structure, the filters acting as additional predictors and helping to meet the assumption of independence of the residuals (Diniz-Filho \& Bini 2005). The filters selected were those that allowed reduction in the spatial structure of the residuals to non-significant levels. In this process, we used the SAM software package, version 4.0 (Rangel et al. 2010).

\section{Results}

The NMDS ordination analysis yielded three significant axes $(p \leq 0.05)$. The first, second and third axes explained $46.4 \%, 25.7 \%$ and $12.3 \%\left(R^{2}\right)$, respectively, of the variation in relation to the distances of the original $n$-dimensional space. Due to the considerably lower $R^{2}$ of the third axis, we chose to present and discuss only the results of the first two.

The classification categories, particularly their top-tier vegetation types, thermal regimes and elevational belts, were consistently discriminated in the first axis (Fig. 2, Tab. 1). The broadleaved dwarf forests, one of the top-tier vegetation types, was split into two sets (Fig. 2a): maritime and montane. We observed statistically significant difference for all elevational belts except for the lower and upper montane belts (Tab. 1). All attributes showed at least one significant difference on the second axis (Fig. 2, Tab. 2). Nevertheless, broadleaved dwarf forest and mixed (broadleaved and needle-leaved) forest did not differ statistically, as was the case for the coastal, lowerplains and upper highlands elevational zones, as well as for the maritime and rain climatic regimes (Tab. 2).

\section{Discussion}

It is well known that plant species distribution varies worldwide across vegetation physiognomies, climatic conditions and elevational gradients (Holdridge 1947; Ledru 1993; Oliveira-Filho \& Fontes 2000; Gaston 2003; Santos et al. 2012). We also know, more specifically in the Atlantic Forest Biome, that a number of factors, such as precipitation, temperature and altitude, affect the distribution of tree species (Oliveira-Filho \& Fontes 2000; Oliveira-Filho et al. 2005; Oliveira 2006; Cerqueira 2011; Marques et al. 2011; Santos et al. 2011). This was the first formal study evaluating the floristic consistency of vegetation classification systems, following a rigorous statistic treatment with a large dataset, in this biome. We provide here a new conception of the Oliveira-Filho system, showing some remarkable phytogeographic aspects.

First, we detected consistent floristic differentiation among the three top-tier vegetation types-broadleaved forest; mixed (broadleaved and needle-leaved) forest, or Araucaria forest; and broadleaved dwarf forest. In the case of broadleaved dwarf forests, the main driving forces of this dissociation typically include the restrictive environments of peripheral areas of the Atlantic Forest Biome, such as coastal sand dunes and rocky mountain tops (Scarano 2002). Extremes of low temperature play a similar role in the case of Araucaria forests (Oliveira-Filho et al. 2013). Romariz (1996) highlighted the physiognomic variations between broadleaved forests and Araucaria forests and stated that there should also be a strong floristic differentiation. According 

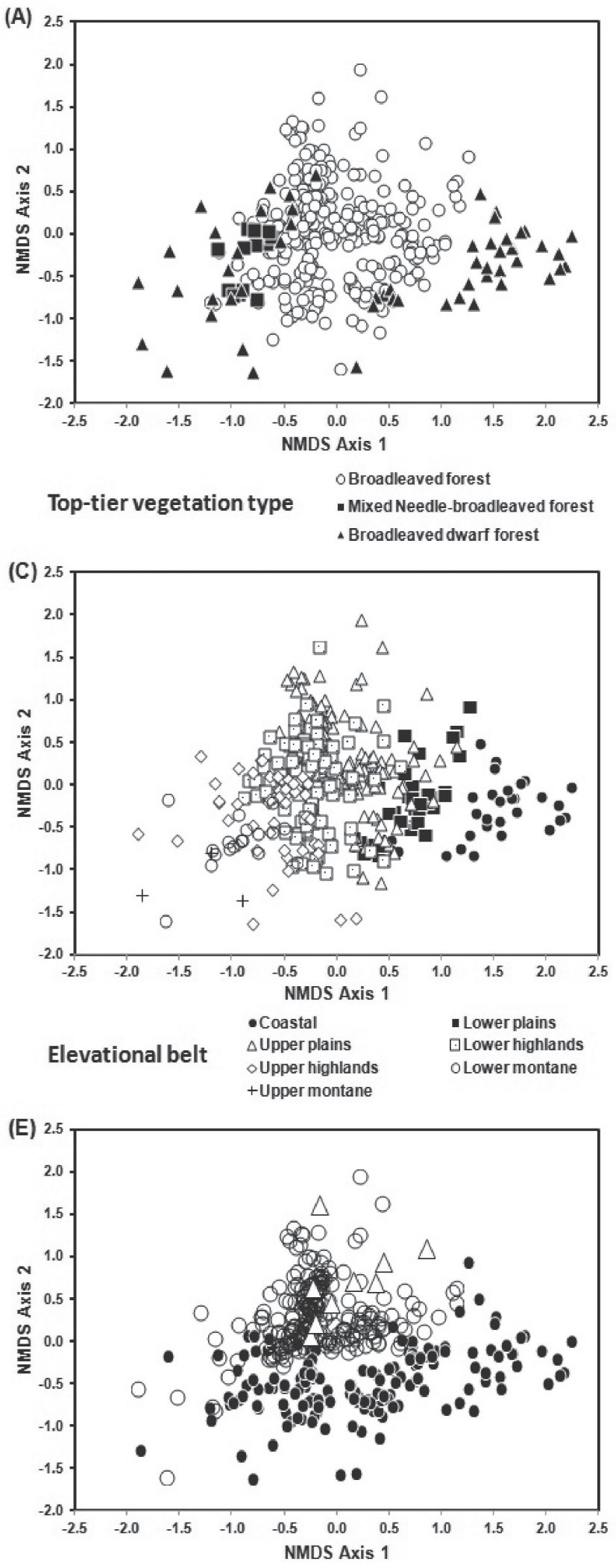

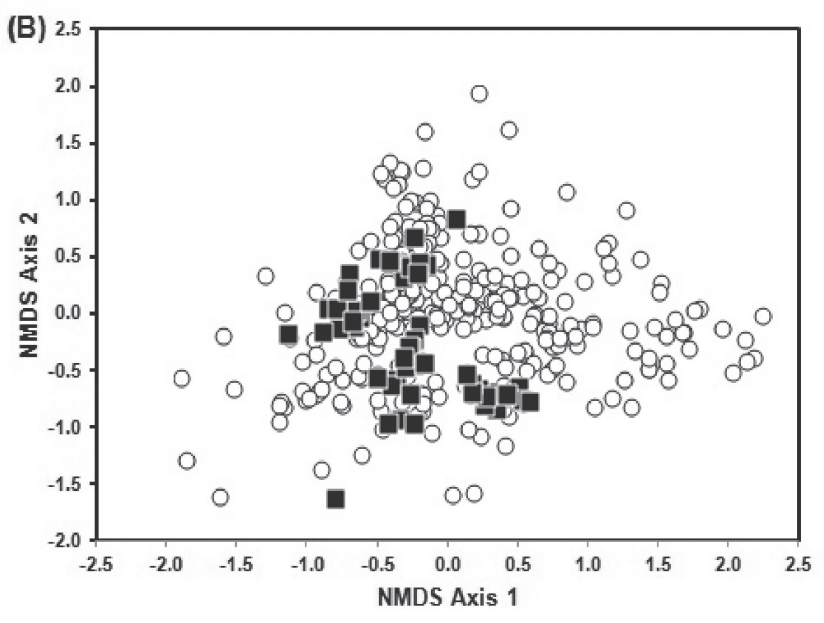

Thermal regime oTropical Subtropical

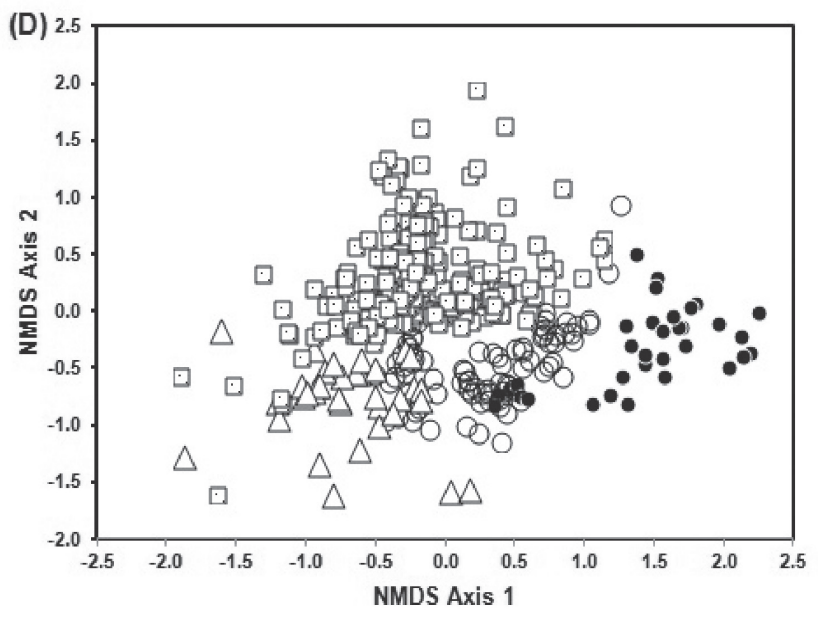

$\begin{array}{lll}\text { Climatic regime } & \text { Maritime } & \text { oRain } \\ \Delta \text { Cloud } & \square \text { Seasonal }\end{array}$ 
Tree species composition in areas of Atlantic Forest in southeastern Brazil is consistent with a new system for classifying the vegetation of South America

Table 1. Multifactorial ANOVA for Axis 1 of the non-metric multidimensional scaling ordination.*

\begin{tabular}{|c|c|c|c|c|}
\hline \multirow{2}{*}{ Category } & \multicolumn{3}{|c|}{$F$ test } & \multirow{2}{*}{ Post hoc comparisons ${ }^{* *}$} \\
\hline & $\mathrm{F}$ & MS & $p$ & \\
\hline \multirow{3}{*}{ Top-tier vegetation type } & \multirow{3}{*}{28.67} & \multirow{3}{*}{1.33} & \multirow{3}{*}{$<0.0001$} & Broadleaved forest ${ }^{\mathrm{a}}$ \\
\hline & & & & Broadleaved dwarf forest $\mathrm{t}^{\mathrm{b}}$ \\
\hline & & & & Mixed (broadleaved and needle-leaved) forest \\
\hline \multirow{2}{*}{ Thermal regime } & \multirow{2}{*}{5.12} & \multirow{2}{*}{0.24} & \multirow{2}{*}{0.0242} & Tropical $^{a}$ \\
\hline & & & & Subtropical ${ }^{\mathrm{b}}$ \\
\hline \multirow{7}{*}{ Elevational belt } & \multirow{7}{*}{44.21} & \multirow{7}{*}{2.06} & \multirow{7}{*}{$<0.0001$} & Coastal $^{\mathrm{a}}$ \\
\hline & & & & Lower plains ${ }^{b}$ \\
\hline & & & & Upper plains $^{c}$ \\
\hline & & & & Lower highlands ${ }^{\mathrm{d}}$ \\
\hline & & & & Upper highlands ${ }^{\mathrm{e}}$ \\
\hline & & & & Lower montane $^{f}$ \\
\hline & & & & Upper montane $^{\mathrm{f}}$ \\
\hline Climatic regime & 0.87 & 0.04 & 0.4192 & - \\
\hline Leaf-flush regime & 1.41 & 0.07 & 0.2459 & - \\
\hline
\end{tabular}

MS: mean square.

${ }^{*}$ Seven filters were added to deal with the spatial structure ( $\Sigma$ MS of the filters $\left.=15.21\right)$. Degrees of freedom (residuals) $=367 ;$ MS (residuals) $=0.05$.

${ }^{*}$ Different letters (within each of the five classification categories) indicate that means differed statistically ( $\left.\leq 0.05\right)$ in an adapted version of Tukey's post hoc honestly significant difference test.

Table 2. Multifactorial ANOVA for Axis 2 of the non-metric multidimensional scaling ordination. ${ }^{*}$

\begin{tabular}{|c|c|c|c|c|}
\hline \multirow{2}{*}{ Category } & \multicolumn{3}{|c|}{ F test } & \multirow{2}{*}{ Post hoc comparisons ${ }^{* *}$} \\
\hline & $\mathrm{F}$ & MS & $p$ & \\
\hline \multirow{3}{*}{ Top-tier vegetation type } & \multirow{3}{*}{3.70} & \multirow{3}{*}{0.27} & \multirow{3}{*}{0.0257} & Broadleaved forest $\mathrm{t}^{\mathrm{a}}$ \\
\hline & & & & Broadleaved dwarf forest $\mathrm{t}^{\mathrm{b}}$ \\
\hline & & & & Mixed (broadleaved and needle-leaved) forest ${ }^{b}$ \\
\hline \multirow{2}{*}{ Thermal regime } & \multirow{2}{*}{21.77} & \multirow{2}{*}{1.58} & \multirow{2}{*}{$<0.0001$} & Tropical $^{\mathrm{a}}$ \\
\hline & & & & Subtropical ${ }^{\mathrm{b}}$ \\
\hline \multirow{7}{*}{ Elevational belt } & \multirow{7}{*}{8.14} & \multirow{7}{*}{0.59} & \multirow{7}{*}{$<0.0001$} & Coastal $^{a}$ \\
\hline & & & & Lower plains ${ }^{\mathrm{a}}$ \\
\hline & & & & Upper plains ${ }^{\mathrm{b}}$ \\
\hline & & & & Lower highlands ${ }^{c}$ \\
\hline & & & & Upper highlands ${ }^{\mathrm{a}}$ \\
\hline & & & & Lower montane $^{\mathrm{d}}$ \\
\hline & & & & Upper montane $e^{\mathrm{d}}$ \\
\hline \multirow{4}{*}{ Climatic regime } & \multirow{4}{*}{4.18} & \multirow{4}{*}{0.30} & \multirow{4}{*}{0.0161} & Maritime $^{\mathrm{a}}$ \\
\hline & & & & Rain $^{\mathrm{a}}$ \\
\hline & & & & Cloud $^{\mathrm{b}}$ \\
\hline & & & & Seasonal $^{\mathrm{c}}$ \\
\hline \multirow{3}{*}{ Leaf-flush regime } & \multirow{3}{*}{1.41} & \multirow{3}{*}{0.07} & \multirow{3}{*}{0.2459} & Evergreen $^{\mathrm{a}}$ \\
\hline & & & & Semideciduous ${ }^{\mathrm{b}}$ \\
\hline & & & & Deciduous $^{\mathrm{c}}$ \\
\hline
\end{tabular}

MS: mean square.

${ }^{*}$ Twenty filters were added to deal with the spatial structure $(\Sigma$ MS of the filters $=18.63)$. Degrees of freedom (residuals) $=360$; MS (residuals) $=0.07$.

${ }^{*}$ Different letters (within each of the five classification categories) indicate that means differed statistically $(\mathrm{p} \leq 0.05)$ in an adapted version of Tukey's post hoc honestly significant difference test. 
to the literature, the predominant tree taxa in broadleaved forests include Aspidosperma spp., Euterpe edulis Mart., Ficus spp., Astronium graveolens Jacq., Platymiscium pubescens, Cedrela fissilis Vell., and Cabralea canjerana (Vell.) Mart. (Romariz 1996; Oliveira-Filho \& Fontes 2000), whereas the physiognomy of Araucaria forests is characterized by the dominance of tall trees of Araucaria angustifolia (Bertol.) Kuntze over species of the lower strata, such as Cedrela fissilis Vell, Podocarpus lambertii Klotzsch ex Endl., Ocotea spp., Nectandra spp., Piptocarpha spp., and Solanum spp. (Romariz 1996, Lista de Espécies da Flora do Brasil 2013). Dwarf forests were split into two groups, corresponding to marginal environments of the Atlantic Forest Biome. Montane dwarf forests are typically rich in species of the genera Myrceugenia, Agarista, Baccharis, Ilex, Weinmannia and Symplocos (França \& Stehmann 2004). Coastland dwarf forests are characterized by a rather different species composition, with a predominance of Clusia spp., Eugenia spp., Myrcia spp., and Myrsine spp. (Magnago et al. 2012)abundance and richness of species along a forest gradient with varying soils and flood regimes. The forests are located on the left bank of the lower Jucu River, in Jacarenema Natural Municipal Park, Espírito Santo. A survey of shrub/tree species was done in 80 plots, $5 \times 25 \mathrm{~m}$, equally distributed among the forests studied. We included in the sampling all individuals with $>3.2 \mathrm{~cm}$ diameter at breast height $(1.30 \mathrm{~m}$. The floristic singularity of each of those major vegetation types was therefore formally confirmed in the present study.

We found a strong differentiation between the tropical and subtropical tree floras. This suggests a latitudinal effect, which carries a set of underlying variables, on the floristic patterns of areas of Atlantic Forest, as was noted first by Siqueira (1994) and subsequently by others (Oliveira-Filho \& Fontes 2000; Oliveira-Filho et al. 2005). Siqueira (1994) found two floristic blocks for the Atlantic Forest: one in the northeastern region of Brazil; and the other within the southern and southeastern regions. Considering both the Atlantic Forest sensu stricto and the semideciduous Atlantic Forest, OliveiraFilho \& Fontes (2000) suggested that the latitudinal pattern could be related to thermal and rainfall regimes. OliveiraFilho et al. (2005) confirmed this latitudinal pattern on a more restricted scale (in the eastern basins, which encompass parts of the states of Bahia, Minas Gerais, Espírito Santo, and Rio de Janeiro). Thus, the tropical vs. subtropical floristic distinction detected in the present study confirmed previous findings and indicated a response not only to thermal patterns but also to other variables summarized by latitude. Species representative of this dichotomy include Melanoxylon brauna Schott, Sorocea guilleminiana Gaudich. and Mabea fistulifera Mart., for the tropical regime; and Solanum sanctaecatharinae Dunal, Matayba intermedia Radlk. and Terminalia australis Cambess., for the subtropical regime.

Another consistent fit between the Oliveira-Filho system and the floristic patterns investigated here was found for the elevational belts. The correlation between elevational varia- tion and floristic patterns of trees has been widely reported for tropical forests (Gentry 1988; Auerbach \& Shmida 1993; Vazquez \& Givnish 1998; Oliveira-Filho \& Fontes 2000; Zhao et al. 2005). Elevational variations are related to environmental heterogeneity, and this has proved crucial to the growth and maintenance of biodiversity in tropical forests, because it tends to provide a greater variety of habitats and microclimates, thereby allowing the coexistence of greater numbers of species (Ricklefs 1977; Rosenzweig 1995; Leigh Jr. et al. 2004). Examples of species typical of lower altitudes include Dialium guianense (Aubl.) Sandwith, Protium icicariba (DC.) Marchand and Handroanthus heptaphyllus Mattos, whereas higher altitudes are represented by Cinnamomum glaziovii (Mez) Kosterm. Croton organensis Baill. and Solanum pseudoquina A.St.-Hil.

Our results indicate that the Oliveira-Filho system is highly appropriate for classifying tree species in areas of Atlantic Forest in southeastern Brazil. In addition, we found that the more detailed physiognomic and ecological features introduced by the new system are sufficiently consistent to allow reliable and meaningful use by any researcher intending to work at scales smaller than those prescribed by the IBGE system. This opens perspectives for further assessments of this new classification system for use in other parts of extraAndean South America, as well as for use in classifying species with other growth habits, such as herbs, climbers and epiphytes. We believe that such studies will not only help solidify the position of this new system but will also contribute to expanding the knowledge of the patterns and underlying driving forces of the distribution of vegetation.

\section{Acknowledgments}

We are grateful to Paulo Sérgio Morandi, of the Universidade do Estado de Mato Grosso (UNEMAT, State University of Mato Grosso, Nova Xavantina campus), as well as to both anonymous reviewers, for their valuable contributions. This study received financial support from the Brazilian Conselho Nacional de Desenvolvimento Científico $e$ Tecnológico (CNPq, National Council for Scientific and Technological Development; Postdoctoral Research Grant no. 303458/2010-0 to PVE and Scientific Productivity Grant no. 303458/2010-0 to ATOF).

\section{References}

Auerbach, M. \& Shmida, A. 1993. Vegetation Change Along an Altitudinal Gradient on Mt Hermon, Israel - No Evidence for Discrete Communities. The Journal of Ecology 81: 25-33.

Batalha, M.A. 2011. O cerrado não é um bioma. Biota Neotropica 11: 21-24.

Borcard, D. \& Legendre, P. 2002. All-scale spatial analysis of ecological data by means of principal coordinates of neighbour matrices. Ecological Modelling 153: 51-68.

Cerqueira, R.M. 2011. Padrões de variação da diversidade alfa na Floresta Pluvial Atlântica brasileira. Tese de Doutorado, Instituto de Biologia, Universidade Estadual de Campinas, Campinas. 2011. 
Coutinho, L.M. 2006. O conceito de bioma. Acta Botanica Brasilica 20: $13-23$.

Diniz-Filho, J.A.F.; Bini, L.M. \& Hawkins, B.A. 2003. Spatial autocorrelation and red herrings in geographical ecology. Global Ecology and Biogeography 12: 53-64.

Diniz-Filho, J. \& Bini, L.M. 2005. Modelling geographical patterns in species richness using eigenvector-based spatial filters. Global Ecology and Biogeography 14: 177-185.

Fernandes, A. 2000. Fitogeografia brasileira - Províncias floristicas. Fortaleza, Realce Editora e Indústria Gráfica Ltda.

Fortin, M.-J. \& Dale, M. 2005. Spatial Analysis - A guide for ecologists. Cambridge, Cambridge University Press.

França, G.S. \& Stehmann, J.R. 2004. Composição florística e estrutura do componente arbóreo de uma floresta altimontana no município de Camanducaia, Minas Gerais, Brasil. Revista Brasileira de Botânica 27: 19-30.

Gaston, K. 2003. The Structure and Dynamics of Geographic Ranges. Oxford, Oxford University Press.

Gentry, A. 1988. Changes in plant community diversity and floristic composition on environmental and geographical gradients. Annals of the Missouri Botanical Garden 75: 1-34.

Giulietti, A.M.; Harley, R.M.; Queiroz, L.P.D.E.; Wanderley, M.D.G.L. \& van den Berg, C. 2005. Biodiversidade e conservação das plantas no Brasil. Megadiversidade 1: 52-61.

Holdridge, L. 1947. Determination of world plant formation from simple climate data. Science 105: 367-368.

IBGE. 2012. Manual Técnico da Vegetação Brasileira. Rio de Janeiro, Instituto Brasileiro de Geografia e Estatistica.

Joly, C.A.; Assis, M.A.; Bernacci, L.C.; Tamashiro, J.Y.; Campos, M.C.R.; Gomes, J.A.M.A.; Sanchez, M.; Santos, F.A.M.; Pedroni, F.; Pereira, L.S.; Padgurschi, M.C.G.; Prata, E.M.B.; Ramos, E.; Torres, R.B.; Rochelle, A.; Martins, F.R.; Alves, L.F.; Vieira, S.A.; Martinelli, L.A.; Camargo, P.B.; Aidar, M.P.M.; Eisenlohr, P.V.; Simões, E.; Villani, J.P. \& Belinello, R. 2012. Florística e fitossociologia em parcelas permanentes da Mata Atlântica do sudeste do Brasil ao longo de um gradiente altitudinal. Biota Neotropica 12: 125-145.

Ledru, M. 1993. Late Quaternary environmental and climatic changes in central Brazil. Quaternary Research 80: 107-138.

Leigh Jr., E.; Davidar, P.; Dick, C.W.; Terborgh, J.; ter Steege, H. \& Wright, S.J. 2004. Why Do Some Tropical Forests Have So Many Species of Trees ? Biotropica 36: 447-473.

Lista de Espécies da Flora do Brasil. 2013. http://reflora.jbrj.gov.br/jabot/ listaBrasil (access on Feb 2013)

Magnago, L.F.S.; Martins, S.V.; Schaefer, C.E.G.R. \& Neri, A.V. 2012. Restinga forests of the Brazilian coast: richness and abundance of tree species on different soils. Anais da Academia Brasileira de Ciências 84: 807-822.

Marques, M.C.M.; Swaine, M.D. \& Liebsch, D. 2011. Diversity distribution and floristic differentiation of the coastal lowland vegetation: implications for the conservation of the Brazilian Atlantic Forest. Biodiversity and Conservation 20: 153-168.

McCune, B. \& Grace, J.B. 2002. Analysis of Ecological Communities. Gleneden Beach, MjM Software Design.

McCune, B. \& Mefford, M. 2011. PC-ORD - Multivariate Analysis of Ecological Data. Version 6.0. Gleneden Beach, MjM Software.

Mittermeier, R.; Robles, G.P.; Hoffmann, M.; Pilgrim, J.; Brooks, T.; Mittermeier, C.G.; Lamoreux, J. \& Fonseca, G.A.B. 2004. Hotspots revisited. Monterrey, Cemex.

Myers, N.; Mittermeier, R.A.; Mittermeier, C.G.; Da Fonseca, G.A. \& Kent, J. 2000. Biodiversity hotspots for conservation priorities. Nature 403: 853-858.

Oliveira, R.J. 2006. Variação da composição florística e da diversidade alfa das florestas atlânticas no estado de São Paulo. Tese de Doutorado, Instituto de Biologia, Universidade Estadual de Campinas, Campinas. 2006.

Oliveira-Filho, A.T. 2009. Classificação das fitofisionomias da América do Sul cisandina tropical e subtropical: proposta de um novo sistema - prático e flexível - ou uma injeção a mais de caos? Rodriguésia 60: 237-258.

Oliveira-Filho, A.T.; Budke, J.C.; Jarenkow, J.A.; Eisenlohr, P.V. \& Neves, D.R.M. 2013. Delving into the variations in tree species composition and richness across South American subtropical Atlantic and Pampean forests. Journal of Plant Ecology (online first) http://www.dx.doi. org/10.1093/jpe/rtt058 (access on Dec 2013).
Oliveira-Filho, A.T. \& Fontes, M.A.L. 2000. Patterns of floristic differentiation among Atlantic Forests in Southeastern Brazil and the influence of climate. Biotropica 32: 793-810.

Oliveira-Filho, A.T.; Tameirão-Neto, E.; Carvalho, W.A.; Werneck, M.; Brina, A.E.; Vidal, C.V.; Rezende, S.C. \& Pereira, J.A.A. 2005. Análise florística do compartimento arbóreo de áreas de Floresta Atlântica sensu lato na região das bacias do Leste (Bahia, Minas Gerais, Espírito Santo e Rio de Janeiro). Rodriguésia 56: 185-235.

Rangel, T.F.; Diniz-Filho, J.A.F. \& Bini, L.M. 2010. SAM: a comprehensive application for Spatial Analysis in Macroecology. Ecography 33: 46-50.

Ribeiro, M.C.; Martensen, A.C.; Metzer, J.P., Tabarelli, M.; Scarano, F. \& Fortin, M.-J. 2011. The Brazilian Atlantic Forest: a shrinking biodiversity hotspot. Pp.405-434. In: Zachos, F.E. \& Habel, J.C. (Eds.). Biodiversity hotspots: distribution and protection of conservation priority areas. Heidelberg/Dordrecht/London/New York, Springer.

Ribeiro, M.C.; Metzger, J.P.; Martensen, A.C.; Ponzoni, F.J. \& Hirota, M.M. 2009. The Brazilian Atlantic Forest: How much is left, and how is the remaining forest distributed? Implications for conservation. Biological Conservation 142: 1141-1153.

Ricklefs, R. 1977. Environmental heterogeneity and plant species diversity: a hypothesis. American Naturalist 111: 376-381.

Romariz, D. 1996. Aspectos da vegetação do Brasil. São Paulo, Edição da Autora.

Rosenzweig, M. 1995. Species diversity in space and time. Cambridge, Cambridge University Press.

Saiter, F.Z.; Guilherme, F.A.G.; Thomaz, L.D. \& Wendt, T. 2011. Tree changes in a mature rainforest with high diversity and endemism on the Brazilian coast. Biodiversity and Conservation 20: 1921-1949.

Santos, M.F.; Serafim, H. \& Sano, P.T. 2011. An analysis of species distribution patterns in the Atlantic Forests of Southeastern Brazil. Edinburgh Journal of Botany 68: 373-400.

Santos, R.M.; Oliveira-Filho, A.T.; Eisenlohr, P.V.; Queiroz, L.P.; Cardoso, D.B.O.S. \& Rodal, M.J.N. 2012. Identity and relationships of the Arboreal Caatinga among other floristic units of seasonally dry tropical forests (SDTFs) of north-eastern and Central Brazil. Ecology and Evolution 2: 409-428.

Scarano, F.R. 2002. Structure, function and floristic relationships of plants communities in stressful habitats marginal to Brazilian Atlantic Rainforest. Annals of Botany 90: 517-524.

Siqueira, M.F. 1994. Análise florística e ordenação de espécies arbóreas da Mata Atlântica através de dados binarios. Dissertação de Mestrado, Instituto de Biologia, Universidade Estadual de Campinas, Campinas. 1994.

Smith, R. 1971. The effect of unequal group size on Tukey's HSD procedure. Psychometrika 36: 31-34.

Stehmann, J.R.; Forzza, R.C.; Salino, A.; Sobral, M.; Costa, D.P. \& Kamino, L.H.Y. 2011. Plantas da Floresta Atlântica. Rio de Janeiro, Jardim Botânico do Rio de Janeiro.

Thomaz, L. \& Monteiro, R. 1997. Composição florística da Mata Atlântica de encosta da Estação Biológica de Santa Lúcia, município de Santa Teresa-ES. Boletim do Museu de Biologia Mello Leitão 7: 3-48.

Vazquez, J.A. \& Givnish, T.J. 1998. Altitudinal gradients in Tropical Forest composition, structure, and diversity in the Sierra de Manantlan. Journal of Ecology 86: 999-1020.

Veloso, H.; Rangel-Filho, A. \& Lima, J. 1991. Classificação da vegetação brasileira, adaptada a um sistema universal. Rio de Janeiro, Fundação Instituto Brasileiro de Geografia e Estatistica.

Werneck, M.D.S.; Sobral, M.E.G.; Rocha, C.T.V.; Landau, E.C. \& Stehmann, J.R. 2011. Distribution and Endemism of Angiosperms in the Atlantic Forest. Natureza \& Conservação 9: 188-193.

Wildi, O. 2010. Data Analysis in Vegetation Ecology. Chichester, WileyBlackwell.

Zachos, F. \& Habel, J. 2011. Biodiversity hotspots: distribution and protection of conservation priority areas. Heidelberg/Dordrecht/ London/New York, Springer.

Zar, J. 2010. Biostatistical Analysis. Upper Saddle River, Prentice Hall.

Zhao, C.-M.; Chen, W.-L.; Tian, Z.-Q. \& Xie, Z.-Q. 2005. Altitudinal Pattern of Plant Species Diversity in Shennongjia Mountains, Central China. Journal of Integrative Plant Biology 47: 1431-1449. 